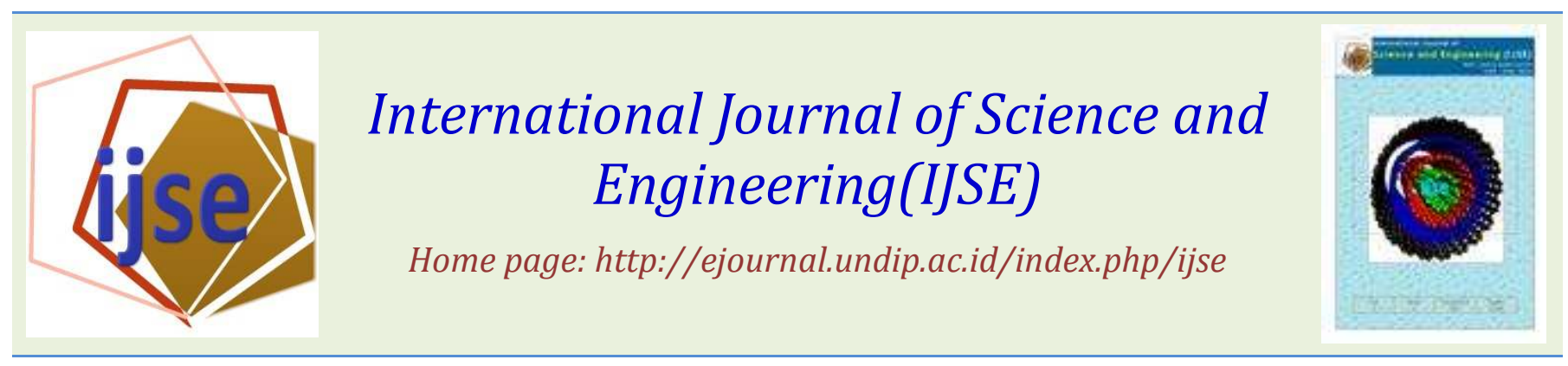

\title{
Changes on the Physical-Chemical Properties of Kue Delapan Jam on Various Steaming Time
}

\author{
Sri Agustini\#), Gatot Priyanto, Basuni Hamzah, Budi Santoso, and Rindit Pambayun \\ \#)Departement of Agriculture, Sriwijaya University, Palembang, Indonesia 30139 Tel.:+62711354222 \\ Email: sragustini@yahoo.com
}

\begin{abstract}
This research intended to study browning reaction between glucose, fructose, and lipids with amino acids in real system during making Kue Delapan Jam. Research applied completely randomized design with steaming time as treatment (2, 4, 6, and 8 hours) with 3 replication. The development of color and browning index were ivestigated by using lightness, redness, yellowness, and total color difference (TCD) during reaction, and the absorbance of methanol extracts was measured at $420 \mathrm{~nm}$ in $40.0 \mathrm{~mm}$ silica. The development of texture was monitored by using Bookfield texture analyzer. Test results showed that steaming time influenced the color, browning index, texture, protein, and fat content of the cake significantly. Steaming time has no effect on water content. There were positive correlation between steaming time with TDC, redness, texture, and browning index during course. While for lightness, yellowness, $p H$, protein, and fat content indicated negative correlation. Changes on texture, TDC, browning index, protein, and fat content followed linear model.
\end{abstract}

Keywords-Kue delapan jam; physics- chemical properties; steaming time.

Submission: September 18, 2014

Corrected : October 8, 2014

Accepted: October 13, 2014

Doi: $10.12777 /$ ijse.7.2.161-165

[How to cite this article: Agustini, S., Priyanto, G., Hamzah, B., Santoso, B., and Pambayun, R. (2014). Changes on the Physical-Chemical Properties of Kue Delapan Jam on Various Steaming Time, International Journal of Science and Engineering, 7(2),161-165. Doi: 110.12777/ijse.7.2.161-165]

\section{INTRODUCTION}

The Kue delapan jam is a traditional cake of Palembang area. It is made from eggs, sugar, sweetened condensed milk and margarine which steamed for 8 hours. Physically KDJ is brown in color, soft textured with a fairly high water content of $>40 \%$.

In making KDJ, browning and texture are important determinant of quality. KDJ which is less brown considered not quite meet the quality requirements. Similarly for the texture, KDJ which look like soft and less dense deemed not meet quality requirements. Browning and texture are major problem in the processing KDJ. The formation of brown pigment and dense texture are very slow so it takes as long as 8 hours to get good quality of cake.

The brown color of KDJ comes from the browning reaction that occurs during steaming. Browning reaction occurs via the Maillard reaction and lipid oxidation. Maillard reaction occurs between the carbonyl compounds (fructose and glucose) with amino acids, protein, and peptide (Saltmarch and Labuza, 1982; Ames, 1990; Nursten, 2005; $\mathrm{Yu}$ and Zhang, 2010; Bastos et al., 2012). Maillard reaction causes the formation of $\mathrm{H}^{+}$ions, thus lowering the $\mathrm{pH}$ of the system. The decline in $\mathrm{pH}$ causes the rate of Maillard reaction decreases (Saltmarch and Labuza, 1982; Nursten, 2005). Additionally decreasing in $\mathrm{pH}$ also caused by the formation of short-chain carboxylic acids such as acetic acid and formic acid (Martins and van Boekel, 2001; Nursten 2005; RufianHanares, 2006). Steaming process caused a decline in the $\mathrm{pH}$ of the system that affects the formation of brown color. The decrease in $\mathrm{pH}$ leads to delayed formation of brown color on KDJ so it takes a long time to get the desired level of browning.

Browning also occured in the processing of foods containing lipids as a result of lipid oxidation. The products of lipid oxidation then react with amines, amino acids and proteins (Hidalgo and Zamora, 2000; Zamora and Hidalgo, 2005). Oxidation of lipids in food can occur in non-enzymatic reaction that known as auto-oxidation reaction. Auto oxidation occurs through a free radical mechanism and hydro peroxide. Hydro peroxides and free radicals are very reactive so they forms a complex reaction such as degradation and 
interactions to produce brown oxypolimer (Hidalgo and Zamora, 2000; Zamora and Hidalgo, 2005).

Browning can be used indirectly in predicting the compounds present in a material, because it is easy and can be done quickly. Tristimulus color measurement has been used effectively in calculating the reaction rate of constants and activation energies on non-enzymatic discoloration (Ibarz, 2000; Lau, et al, 2000; Tosun, 2004; Mohammadi, et al, 2008; Tan, 2012).

Research on the kinetics of color changes on real systems have been carried out widely (Mohammadi, et al, 2008; Bosch, et al, 2007; Hutapea et al, 2004; Tosun, 2004; Lau, et $a l, 2000)$. Most of studies revealed that color changes in the Maillard reaction followed zero-order kinetics (Ibarz, et al, 2000; Tosun, 2004; Mohammadi, et al, 2008; Jaiswal and Abu-Ghannam, 2013). However, those studies are limited to the process of bread making, milk processing and drying vegetable and fruits. Research on the changing of the chemical physical of complex systems have not been widely applied.

This research aims to study the changes on the physicalchemical properties of KDJ includes changes in color, moisture, protein, fat content, and texture formation in various steaming times of KDJ. The study also expected can be applied to predict the physical-chemical properties changes in the processing of other foods that contain carbohydrates, proteins and fats.

\section{MATERIAL AND METHOD}

Materials used in this research were:

1) Raw material for KDJ making consist of hens egg, sucrose, margarine and sweetened condensed milk.

2) Research instrument such as weight scale of Electronic Kitchen Scale Model EK3651 with 2,000, hand mixer, baking pan, autoclave, Hirayama type Hiclave- HVE-50, Konica color reader, desiccators, glassware, incubator, magnetic stirrer, analytical balance, oven, Bookfield Texture Analyzer, Spectrophotometer (Hach).

3) The KDJ was made by mixing $1,500 \mathrm{~g}$ of eggs, $600 \mathrm{~g}$ sugar, $398 \mathrm{~g}$ sweetened condensed milk and $100 \mathrm{~g}$ margarine by using a hand mixer to obtain a homogeneous mixture. The mixture is then poured into the $20 \times 20 \times 7 \mathrm{~cm}$ baking pan that has been smeared with margarine. Then it was covered with aluminum foil to prevent water dropplet on the surface. Steaming process is then performed according to treatment time ( $2 \mathrm{~h}, 4 \mathrm{~h}, 6 \mathrm{~h}$ and $8 \mathrm{~h}$ ). The cake was taken out and air cooled soon after steaming time reached to stop further reaction.

Research apply completely randomized design with 3 replication. The treatment was steaming time consist of $2 \mathrm{~h}, 4$ $\mathrm{h}, 6 \mathrm{~h}$, and $8 \mathrm{~h}$. Data were analyzed by Duncan's multiple range tests using statistical package Statistica V 5.5 software. A significant level was defined as $P<0.05$.

Color was evaluated by using Konica Minolta color Reader measuring L (100 =White, 0=Black), a (+, red; -, green), b (+, yellow; -, blue). A white tile (No: 21733001) was used to standardize the instrument. Total Color Difference (TDC) calculated according to equation:

$$
\mathrm{TDC}=\left(\Delta \mathrm{L}^{2}+\Delta \mathrm{a}^{2}+\Delta \mathrm{b}^{2}\right)^{1 / 2}
$$

The value of $\mathrm{L}_{0}, \mathrm{a}_{0}$, and $\mathrm{b}_{0}$ were measured after the mixture steamed for five minutes, so that the mixture becomes a solid and had flat surface .

Change on texture were measured by using Bookfield texture analyzer with a probe plastic cylinder diameter of 25.4 $\mathrm{mm}$, trigger $100 \mathrm{~g}$, speed of $1.0 \mathrm{~m} / \mathrm{sec}$ with $10 \mathrm{~mm}$ distance. The moisture contents were measured by the difference of the sample weight after drying at $105{ }^{\circ} \mathrm{C}$ for $20 \mathrm{~h}$. Fat contents were determined using the standard method of the Association of Official Analytical Chemists (AOAC, 1990). The protein content was determined by the semi-micro Kjeldahl method (ISO 5983-1-2005).

\section{RESULT AND DISCUSSION}

\section{Moisture Content}

The moisture content of KDJ ranged from 47.6 to $48.9 \%$. This means that statistically the moisture content is relatively the same for all treatment. High levels of moisture showed that steaming process not able to evaporate the water content of the raw materials (dough), during steaming. The longer steaming time does not affect on the moisture content.

\section{Texture}

Test results for the texture showed an increased in texture during steaming. The texture changes during steaming followed a linear pattern. The longer steaming the more compact texture. Steaming time have a very strong correlation $\left(\mathrm{R}^{2}=0.973\right)$ with the rate of increase in texture. This is in accordance with Labuza et al (2008) who also found a linear pattern on change in the texture of whey-based foods during storage.

Texture is one of the most important quality attribute for foods. Change on texture could indicate deterioration in foods. Moisture, composition, $\mathrm{pH}$ and dimension are among factor those influence the texture.

Texture of KDJ were developped during steaming. Texture of KDJ which were steamed for 2 hours relatively softer than that of other treatments. This is due to the accumulation of high molecular weight compounds that are formed as a result of the Maillard reaction is not quite enough, so that the texture is quite soft. More over during steaming proteins interacts each other to form protein agglomeration and the Maillard reaction which affects the color and texture (Labuza, et al, 2008). Analysis of variance on the texture showed that steaming time have significant effect on the texture of KDJ.

\section{Color}

Color is important attribute for foods, caused it can be observed directly. More over color change or color formation can be used to predict reaction stages in food products such Maillard reaction stages (Francis, 1995 in Bastos, et al, 2012).

Brown color on KDJ generated from non enzymatic browning reactions namely Maillard reaction and lipid oxidation during steaming process. Reactants for Maillard reaction derived from sugar (sucrose) and lipids as a source of carbonyl compounds and proteins from eggs and milk as a source of amino acids. The source of lipids for the lipid oxidation derived from egg yolks and margarine.

Test results showed decline in the level of lightness (L) during steaming. Decreasing on the lightness caused by 
browning reaction that occurs during steaming. The longer steaming, the darker color produced. The decrease in lightness during steaming indicates the accumulation of browning pigments which were formed during steaming process more and more. This is consistent with other studies that reported a decrease in the value of the lightness during processing and storage of foods (Ramirez-Jimenez, et al, 2000; Tosun, 2004; Coghe et al, 2006; Bosch et al, 2007; Mohammadi, et al, 2008; Matsuo, et al, 2012; Tan et al, 2012).

Analysis of variance showed that steaming time have significant effect on the lightness of KDJ. This result indicated that the rate of browning increase with increasing steaming time.

In contrast to lightness, the redness (+a) of KDJ was increasing consistently. The longer steaming, the higher redness. This is an accordance with other studies that also reported an increasing of redness during processing and storage of food (Tosun, 2004; Bosch et al, 2007; Mohammadi, et al, 2008; Capuano et al, 2008; Matsuo, et al, 2012; Zaman and Yang, 2013). Steaming time have a very strong correlation (linear regression $\mathrm{R}^{2}=0.92$ ) with the rate of increasing of redness.

Analysis of variance showed that steaming time has significant effect on the redness of KDJ. Duncan test showed there were significant difference on the redness of KDJ which were steamed for 8 hours with those were steamed for 6 hours, 4 , hours and 2 hours.

As for yellowness, steaming time resulted decrease in yellowness (b). This is in accordance with other studies which reported decreasing in yellowness during processing and storage of foods (Ibarz, et al, 2000; Tosun, 2004; Mohammadi, 2007).

Analysis of variance showed that steaming time have significant effect on the yellowness of KDJ. There were significant difference on the yellowness of KDJ which were steamed 8 hours with those were steamed for 2 hours and 4 hours.

The changes on the color of the cake during steaming were calculated as Total color difference (TDC). There were linear increasing of TDC during steaming. In the early stages there were significant increase in TDC. This indicated positive correlation between steaming time with rate of increase of TDC. The longer steaming, the higher change in TDC.

\section{Browning Index}

Browning on KDJ considered to be desirable caused it enhances the appearance and flavour in terms of tradition and consumer acceptance. Rate of browning reactions depends on temperature, $\mathrm{pH}$, moisture content, time of heat treatment, the concentration and nature of the reactants (Saltmarch and Labuza, 1982).

Test result showed the increased in browning index during course. The longer steaming time, the higher browning index. Steaming time have significan effect on the browning index. This indicated the occurrence of the Maillard reaction and melanoidin formation during steaming. This result in accordance with numerous studies that showed the Maillard reaction is influenced by the type of reactants and duration of heating (Ames, 1998; Bosch, et al, 2007; Zaman and Yang, 2013).
Analysis of variance showed that steaming time influenced the browning index significantly. There were significant difference on the browning index which was steamed for 8 hours with those steamed for 6 hours. There were strong correlation between steaming time and rate of browning. Rate of browning increased with increasing steaming time. The difference on the browning index is due to melanoidin formation during steaming. The 2 hours steaming only produced brown pigment slightly. In the contrary steaming for 6 hours, and 8 hours, the brown pigment produced have accumulated quite a lot so it gave significant difference in browning index.

\section{Fat Content}

Test result on fat content showed a decreased during steaming. This was becaused the fat undergo auto-oxidation due to heat treatment to becomes hydroperoxide.The next step is degradation of hydroperoxides to become aldehydes and hydro carbon. Finally hydro peroxide and aldehyde polymerize into stable products and brown products (Hidalgo and Zamora, 2000, Fennema, 1996). In addition during steaming Maillard reaction also took place. Maillard reaction between lipid oxidation products with amines, amino acids and proteins cause browning in food processing (Hidalgo and Zamora, 2000). All reaction series during steaming caused decreasing fat content on the cake.

Analysis of variance showed that steaming time influenced the fat content significantly. Duncan least square test showed there were significant difference on the fat content of KDJ which was steamed for 8 hours with those steamed for 2,4 hours and 6 hours. There were no significant difference on fat content of KDJ which were steamed for 4 hours and 6 hours.

\section{Protein Content}

Test result on the protein content showed a decreased during steaming. This is becaused during steaming proteins undergo Maillard reaction with carbonyl compound which were derived from lipid oxidation to produce volatile aroma compound such as ammonia, carbon dioxide and strecker aldehyde. This in accordance with Van Ba, et al (2012) which states that amino acids can undergo the Strecker degradation that subsequently produce some reactive radicals such as ammonia, hydrosulfide and etc which also are able to further react with the secondary oxidized products of lipid to produce volatile aroma such as thiols, thiophenes, thiazoles and etc.

Analysis of variance showed that steaming time influenced the protein content significantly. Duncan least square test showed there were significant difference on the protein content which was steamed for 8 hours with that was steamed for 2 hours and the dough $\left(\mathrm{H}_{0}\right)$. No significant difference on the protein content of KDJ which were steamed for 8 hours, 6 hours, and 4 hours.

\section{IV.CONLUSIONS}

The above result showed that the steaming time influence on the physical-chemical properties of KDJ such as texture, color, browning index, protein and fat content. Steaming time have no effect on water content.

During steaming there were increased in texture, browning index, redness (a), and TDC. While for the lightness 
(L), yellowness (b), protein, and fat showed a decreased. Changes in texture, TDC, redness, browning index, protein and fat content followed the linear models. The color, protein and fat content of KDJ which were steamed for 6 hours not significantly difference with were steamed for 8 hours. While as for texture, browning index and total color difference which were steamed for 6 hours significantly differ with were steamed for 8 hours.

Table 1. Physical-chemical properties of KDJ

\begin{tabular}{lcccccccc}
\hline Code & Texture & $\mathrm{L}$ & $\mathrm{a}$ & $\mathrm{b}$ & IB & TDC & Protein $(\%)$ & Fat $(\%)$ \\
\hline $\mathrm{H}_{0}$ & - & $77.70 \mathrm{a}$ & $1.40 \mathrm{a}$ & $24.23 \mathrm{a}$ & - & - & $10.99 \mathrm{a}$ & $14.77 \mathrm{a}$ \\
$\mathrm{H}_{2}$ & $1087.5 \mathrm{a}$ & $64.13 \mathrm{~b}$ & $2.23 \mathrm{a}$ & $21.43 \mathrm{~b}$ & $0.32 \mathrm{a}$ & $16.93 \mathrm{a}$ & $10.42 \mathrm{~b}$ & $12.76 \mathrm{~b}$ \\
$\mathrm{H}_{4}$ & $1232.1 \mathrm{a}$ & $56.03 \mathrm{c}$ & $7.40 \mathrm{~b}$ & $15.57 \mathrm{c}$ & $0.39 \mathrm{a}$ & $27.27 \mathrm{~b}$ & $9.88 \mathrm{c}$ & $9.71 \mathrm{c}$ \\
$\mathrm{H}_{6}$ & $1451.7 \mathrm{~b}$ & $52.67 \mathrm{~d}$ & $9.73 \mathrm{bc}$ & $14.0 \mathrm{~cd}$ & $0.44 \mathrm{ab}$ & $31.66 \mathrm{c}$ & $9.52 \mathrm{c}$ & $7.40 \mathrm{c}$ \\
$\mathrm{H}_{8}$ & $1762.8 \mathrm{c}$ & $50.9 \mathrm{~d}$ & $10.3 \mathrm{c}$ & $12.67 \mathrm{~d}$ & $0.65 \mathrm{c}$ & $33.94 \mathrm{~d}$ & $9.06 \mathrm{c}$ & $5.50 \mathrm{~d}$ \\
\hline
\end{tabular}

*Data represent mean values $(\mathrm{n}=3)$ of the measurements

Means marked with the same letter in each batch are not significantly different $(\mathrm{P}>0.05)$

\section{ACKNOWLEDGMENT}

The author would like to say thank you to the management and staffs Laboratory of Baristand Industry Palembang, for the supports during the research.

\section{REFERENCES}

Ames J. M. 1998, Applications of the Maillard reaction in the food industry. Food Chem, 62:431-439. doi:http://dx.doi.org/10.1016/S0308- 8146(98) $\underline{00078-8 .}$

Bastos,D.M., Monaro,E., Siguemoto, E., and Séfora,M. 2012. Maillard Reaction Products in Processed Food: Pros and Cons in Food Industrial Processes - Methods and Equipment.P.282-296. www.intechopen.com/download/pdf

Borrelli,R.C.,Mennella,C.,Barba,F., Russo, M., Russo,G.L., and Krome, K. 2003. Characterisation of coloured compounds obtained by enzymatic extraction of bakery products. Food and Chemical Toxicology, 41:13671374.doi:10.1016/S0278-6915(03) 00140-6

Bosch,L.,Alegrı'a,A.,Farre,R.,Clemente, G. 2007. Analytical, Nutritional and Clinical Methods Fluorescence and color as markers for the Maillard reaction in milk-cereal based infant foodsduring storage. Food Chem. 105:1135-1143. doi:10.1016/j. food chem.2007.02.016

Capuano, E., Ferrigno, A., Acampa, I., Ait-Ameur,L., and Fogliano,V. 2008. Characterization of the maillard reaction in bread crisps. Eur Food Res Technol, 228:311-319. doi: 10.1007/s00217-008-0936-5.

Delgado-Andrade,C.,Ferrigno,A., Acampa, I.,Ait-Ameur, L, and Fogliano,V. 2008. Characterization of the Maillard reaction in bread crisps. Eur Food Res Technol, 228:311-319. doi: 10.1007/s00217-008-0936-5.

Erge,H.S., Karadeniz,F., Koca,N., Soyer, Y. 2008. Effect of heat treatment on chlorophyll degradation and color loss in green peas. GIDA, 33 (5) : 225-233.www.gidadernegi.org/EN/

Fennema, O.R. 1996. Foods Chemistry.3rd Ed. Marcel Dekker Inc. New York. ISBN 0-8247-9691-8, pp 255-274.

Gerrard, J. A. (2002). Protein-protein crosslinking in food: methods, consequences, applications. Trends Food Science and Technology, Vol 13, No. 12, December, pp. 391-399. doi:10.1016/S0924-2244(02)002571

Hidalgo, F.J., and Zamora, R. 2000. The role of lipids in nonenzymatic browning. Grasas y Aceites, (51): 35-49. digital.csic.es/bitstream/10261 122012

Horszwald, A., Troszyn'ska, A., Dolores del Castillo, M, dan Zielinski, H. 2009. Protein profile and sensorial properties of rye breads. Eur Food Res Technol, 229:875-886. doi: 10.1007/s00217-009-1129-6.

Hutapea, E.B., Parkanyiova, L., Parkanyiova, J., Miyahara, M., Sakurai,H., and Pokorny,J.2004. Browning reactions between oxidised vegetable oils and amino acids. Czech J. Food Sci., 22: 99-107. www.agriculturejournals.cz/ publicFiles/50627.pdf

Ibarz,A., Pagan,J. , Garza,S.2000. Kinetic models of non-enzymatic browning in apple puree. $J$ Sci Food Agric, 80:1162-1168. doi: 10.1002/1097-0010 (200006)80:8<116.
Jaiswal, A.K. and Abu-Ghannam, N. 2013, Degradation kinetic modelling of Colour, Texture, Polyphenols and Antioxidant Capacity of York Cabbage after Microwave Processing. Food Research International. doi: 10.1016/j.foodres. 2013. 04.007

Jing, H., Kitts, D.D. 2002. Chemical and biochemical properties of caseinsugar Maillard reaction products. Food Chem Toxicol, 40(7):1007-15. doi:10.1016/S0278-6915(02)00070-4

Labuza,T., Zhou, P., Liu,X., Davis,L., and Tran, A. 2008. Protein aggregation and hardening of whey based nutritional bars during storage. 5 th International Whey conference, Paris.www.eurofoodwater.eu/pdf/ 2010/Session3/download.

Lau, M.H., Tang, J., Swanson, B.G. 2000. Kinetics of textural and color changes in green asparagus during thermal treatments. Journal of Food Engineering,45:231-236. doi:10.1016/S0260-8774(00)00069-8

Lin-Gu,F., Kim,J.M., Abbas,S., Zhang, X.M.,Xia,S., Chen,Z. 2010. Structure and antioxidant activity of high molecular weight Maillard reaction products from casein-glucose. Food Chem,120:505-511. doi:10.1016/j.foodchem. 2009.10.044.

Martins,S.I.F.S., Jongen, M.F.W., Van Boekel, M.A.J.S. 2001. A review of Maillard reaction in food and implications to kinetic modelling. Trends in Food Science \& Technology,11:364-373. PII:S09242244(01)00022-X

Matsuo,M., Umemura,K., Kawai,S. 2012. Kinetic analysis of color changes in cellulose during heat treatment. Journal of Wood Science, 58(2): 113119.doi:113-119.10.1007/s100 86-011-1235-5.

Mohammadi,A., Rafiee,S.,Emam-Djomeh, Z., Keyhani,A. 2008. Kinetic Models for Colour Changes in Kiwi fruit Slices During Hot Air Drying. World Journal of Agricultural Sciences, 4(3):376383.www.idosi.org/wjas/ wjas4(3)/15.pdf.

Ramirez-Jimenez, A., Guerra-Herna'ndez, E., Garcı'a-Villanova,B. 2000. Browning Indicators in Bread. J. Agric. Food Chem., 48 (9): 4176-4181. doi: $10.1021 /$ jf9907687.

Rufian-Henares,J.A., Delgado-Andrade,C., and Morales,F.J. 2006. Occurrence of acetic and formic acid in breakfast cereals.J.Agric.Food Chem.86(9) : 1321-1327. doi:10.1002/jsfa.2510

Saltmarch,M and Labuza,T.P. 1982. Non enzymatic Browning via the Maillard Reaction in Foods. Diabetes, 31 (Supp13):29-36.doi:10.2337/ diab.31.

Sithole,R., McDaniel,M.R., and Goddik, L.M.2005. Maillard Browning in Sweet Whey Powder. J. Diary Sci., 88(5):1636-1645.http://dx.doi. org/ 10.3168/jds.S0022-0302(05)72835-6

Tan,T.C.,Abbas,F.M.A., Azhar,M.E. 2012. Characterization of the riboseinduced Maillard reaction in minced chicken and minced pork: a potential means of species differentiation. International Food Research Journal,19(2):481-489.www.ifrj. pm. edu.my/19(02)2012/(15)IFRJ

Tosun,I. 2004. Color changes and 5-hydroxymethyl furfural formation in zile pekmezi during storage. Grasas yAceites,55(3):259-263. grasasyaceites.revistas.csic.es/index.php/grasasyaceites/article

Van Ba,H., Hwang,I., Jeong,D., and Touseef, A. 2012. "Principle of Meat Aroma Flavors and Future Prospect". In Isin Akyar. Latest Research into quality control edited. www.intechopen.com/ 
Yilmaz,Y. and Akgun,F.B. 2008. Ferric reducing/antioxidant power of Maillard reaction products in model bread crusts. Journal of Food. Agriculture and Environment, 6(2) : 56-60. http://world-food.net/ferricreducingantioxidant-power-of-maillard-reaction-products-in-modelbread-crusts.

Zamora, R., and Hidalgo, F.J. 2005. Coordinate Contribution of Lipid Oxidation and Maillard Reaction to the Non enzymatic Food Browning.
Critical Reviews in Food Science and Nutrition, 45 (1):49-59. doi:10.1080/10408690590900117.

Zaman, W., Yang, T.A. 2013. Moisture, Color and Texture Changes in Cocoa Seeds during Super heated Steam Roasting. J. Appl. Sci. Res. 9(1):1-7.worldcocoafoundation.org/wp-content/files_mf/ zaman2013 postharvest 